\title{
GODENTE MA NON TROPPO: O mínimo de gozo do outro necessário para a constituição do sujeito
}

\author{
Godente ma non troppo: The minimum of jouissance of the other \\ necessary to the subject constitution
}

\begin{abstract}
Marie-Christine Laznik
Psicanalista, Doutora em Psicologia pela Université de Paris XIII, analista membro da Association Lacanienne Internationale, psicanalista no Centre Alfred Binet, Paris - França, e-mail: mclaznik@club-internet.fr
\end{abstract}

\section{Resumo}

A autora propõe utilizar o conceito lacaniano de gozo como operador central na clínica do autismo, partindo da constatação de que nos bebês cujo encaminhamento se dá rumo a esse quadro clínico pode haver presença de uma relação narcísica com os pais, mas não uma relação pulsional, que desemboque na constituição de um sujeito desejante. Essa constatação, feita a partir da análise de filmes familiares, permite conceber um importante lugar para o tratamento psicanalítico e uma direção de tratamento para bebês com sinais de risco do tipo autístico, em que a questão pulsional entre a criança e seus pais vai ser colocada em evidência.

Palavras-chave: Autismo. Bebês. Pulsão. Narcisismo. Gozo.

\begin{abstract}
This article proposes the use of Jacques Lacan's concept of jouissance as a central operator in the clinic of the autism, based on the observation that in babies inclined to this clinical picture may be the presence of a narcissistic relationship with the parents, but not a drive-relationship, that would lead to the constitution of a desiring subject. This verification, made after analyzing the family movies of the baby, allows conceiving an important place to the psychoanalytic treatment and a direction to the treatment of babies with signs of risk to autism, in which the drive question between the children and their parents will be placed in evidence.
\end{abstract}

Keywords: Autism. Babies. Drive. Narcissism. Jouissance. 
Do argumento de nossas jornadas ${ }^{1}$, interrogarei principalmente a questão da estrutura do grande Outro para a criança e a instauração, ou não, da estrutura de sua fantasia. Na realidade, vou partir da questão do lugar do gozo na constituição do sujeito, desde os primeiros momentos de sua vida, em seu laço com o que vai construir um Outro para ele. Essas reflexões provêm da comparação entre a clínica com bebês comuns e aqueles que já estão se encaminhando para o autismo e cuja patologia vai se revelar em seu esplendor alguns anos mais tarde. Estranhamente, foi em Lacan que encontrei elementos que me permitiram perceber aí alguma coisa.

Digo estranhamente porque Lacan, contrariamente a alguns autores ingleses, não se interessou realmente pelos bebês nem pelo autismo precoce, mas principalmente porque o conceito de gozo que vou empregar - e que certamente é, por sua vez, lacaniano - geralmente é tratado apenas em sua dimensão depreciativa.

Entretanto, no seminário de 1970, O avesso dapsicanálise, Lacan começa a mostrar um outro lado do gozo que, em pequenas doses, tem certamente um papel necessário. Vejamos o que ele diz em 11 de fevereiro de 1970: "mãe que diz, mãe a quem se demanda, mãe que ordena e que institui ao mesmo tempo a dependência do homenzinho. A mulher permite ao gozo ousar a máscara da repetição. [...] Ela ensina seu pequeno a se exibir. Ela conduz ao mais-de-gozar, porque ela mergulha suas raízes, ela, a mulher, como a flor, no gozo mesmo" (Lacan, 1970, p. 73-74).

\section{Primeiro tempo: Godente}

Tentemos decifrar esse texto com a ajuda de uma cena da vida cotidiana entre um bebê normal de 5 meses, Fabien, e sua mãe, que ensina o gozo ao seu filhote. A criança está de fralda e veste uma pequena camisa. Está deitada de costas, sobre uma toalha, num colchonete de trocas, na cama dos pais, onde se acha sentada também a mãe. A cena parece preceder a hora do banho. O bebê olha para a mãe, mas está ocupado sobretudo em chupar seus dois punhos. A mãe lhe diz, com uma voz envolvente: "Vamos ficar peladinho, peladinho, peladinho..." Enquanto profere essa frase, ela retira uma das mãos dele da boca para poder tirar uma manga, mas, no temor de desagradá-lo, redobra sua sedução e começa suavemente a fazer cócegas no peito de seu filho, que abre um grande sorriso. A mãe comenta: "Você dá risadas? Cuti! Cuti! Cuti! Cuti! Cuti!", enuncia, sempre lhe fazendo cócegas suave e ternamente na barriga. Depois ela aproxima o pé do bebê de sua boca, pé que ela vai beijar várias vezes dizendo: "Ela é safada essa mamãe? O que ela está fazendo? Cuti, cuti, cuti, cuti!". O bebê não somente mostra sua satisfação ao se deixar fazer cócegas, tem mesmo sua mão ternamente colocada sobre a de sua mãe, como ainda emite um "aaah" de satisfação pulsional para indicar realmente seu prazer de se encontrar ali no registro freudiano da voz passiva da pulsão. Mas, nesse mesmo seminário $O$ Avesso da Psicanálise, Lacan lembrava que o gozo começa com as cócegas, mas pode acabar em grelhado. O exemplo clínico trazido por Dominique Janin nessas mesmas jornadas, com o desenho da menininha que se fazia assar, nem um pouco suave, espetada pelos lobos, é um exemplo impressionante.

Aqui também, entre esse menininho e sua mãe, a libido oral quase vai chamuscar e éinteressante ver como a mãe vai operar o desembaraço da situação. Estudemos então a sequência da cena erótica, já que o bebê, que se encontrava num registro mais freudiano da voz passiva, vai passar ao registro lacaniano da busca do gozo do Outro. Vejamos como.

A mãe já retirou a pequena camisa. Fabien olha para ela em êxtase e decide levar seus pés até a boca da mãe. Primeiramente o esquerdo, e usa até a mão para estar certo de atingir realmente seu objetivo, proferindo: "Bah!"

A mãe se põe a dar beijinhos na planta desse pezinho colado à sua boca, dizendo: "Como é gostoso este pezinho! É gostoso este pezinho!” Fabien, que não perde uma gota do prazer de sua mãe, põe então sua mão na boca da mãe, que se apressa a cobri-la de beijinhos, dizendo: "A gente comeria um bebê assim! Hum! Hum! Hum!”.

\footnotetext{
1 Trabalho apresentado nas Jornadas da Association Lacanienne Internationale "L'enfant entre désir et jouissance" (A criança entre desejo e gozo), de 10 a 12 de março de 2006, em Paris. Publicado em: Cabiers de l'Association lacanienne internationale. Paris: ALI, 2006. Tradução: Leda Mariza Fischer Bernardino.
} 
Mãe e filho arrulham juntos de um mesmo gozo: “Aaaah!”. Fabien não apenas se faz ativamente comer o pé por sua mãe, como também acompanha no rosto dela e em sua voz a alegria que ele aí suscita.

Então, a mãe solta a fralda sem retirá-la, pois seu filho deseja ainda colocar seu pé na boca de sua mãe, que comenta: "Um pezinho por aqui, eu devoro!", dando um sonoro beijo no pé que lhe é ostensivamente oferecido.

Entretanto, se encontramos aí as condições para que um gozo do Outro possa vir construir este campo Outro e retrospectivamente o campo mesmo do sujeito, ainda é necessário que este outro que a isso se presta não se engane.

\section{Segundo tempo: Ma non troppo}

Convém que a mãe não se tome pelo Outro e saiba que o gozo do Outro, embora ela possa entrevê-lo, é-lhe proibido. Que ela, a mãe, é marcada pela castração e pela proibição do incesto. O gozo, que vai das cócegas ao grelhado, como nos lembra Lacan, opõe-se ao princípio do prazer. No ano seguinte ao seminário em que ele avança que a mãe é aquela que ensina o gozo ao seu filhote, no seminário denominado De um discurso que não fosse semblante, Lacan (1971) acrescenta que é necessário o gozo, certamente, mas não demais. Que ele é proibido por certas coisas que se articulam em torno da questão do princípio do prazer que só pode, diz ele, ter um sentido: nada de gozo demasiado. Desse ponto de vista, o desenho do caso da menininha de Dominique Janin, fazendo-se grelhar no espeto pelos três lobos, é exemplar. Ele mostra o quanto Lacan tem razão quando avança que o estofo de todos os gozos confina ao sofrimento e que é mesmo disso que reconhecemos a aparência.

Mas voltemos a Fabien e sua mãe. Será que é ao se ouvir dizer "devorar" que a mãe desperta de seu devaneio claramente canibalístico? Desde 1905 Freud previra que a sexualidade infantil oral só poderia encontrar as fantasias sexuais canibalísticas nos pais. $\mathrm{O}$ fato é que a mãe, mesmo nunca tendo lido Lacan, mas estando perfeitamente marcada pela castração simbólica, tem um justo saber inconsciente sobre o fato de que o gozo oferecido ao Outro não é para o sujeito que está em um lugar parental, e ela vai se desembaraçar dessa cena, de modo absolutamente tocante, e evitar chegar ao grelhado. O que provavelmente não ocorreu no meio em que vivia a pequena paciente de Dominique Janin.

Enquanto a mãe terminava o beijo no pé de seu menininho, ele tinha agarrado muito atentamente o pé com a mão na intenção provável de deixá-lo realmente na boca da mãe. Mas ela vai perceber a situação e mudar completamente de registro. Ela se põe a admirar o desempenho esportivo de seu filho. Ela recua, pois, da relação erótica, sem abandoná-lo, pois ela se torna, a partir de então, sua admiradora: "Parabéns! Como você segura bem seus pés!", exclama ela. Como o filho dá uma risada de prazer diante do cumprimento, ela acrescenta, falando no lugar dele: "Puxa, como eu sou grande!".

E, com efeito, o que ela diz no lugar dele é justo. Ele está orgulhoso - chuffed-por ter percebido que é a fonte do orgulho de sua mãe. De objeto ele se torna sujeito. Chuffed é um termo de cavalaria. Ele demonstra o orgulho do cavaleiro que venceu um torneio e vai oferecer sua vitória à dama cujas cores ele defende. Esse termo foi proposto por Colwyn Trevarthen (2005), famoso especialista do desenvolvimento dos bebês, segundo o qual a questão do sujeito se coloca bem mais precocemente nos bebês do que nós, psicanalistas, cremos.

Assim, a mãe opera um desembaraço, passando da cena oral-erótica - com sua necessária fantasia de devoração: "A gente comeria um bebê assim!" - para uma dimensão narcísica fálica em que ela admira seu filho: "Parabéns! Como você segura bem seus pés!”. Ela faz cessar o gozo, antes de chegar ao grelhado.

Quando Lacan ([1969-1970] 1992, p. 74) enuncia "a mulher dá ao gozo ousar a máscara da repetição; ela ensina seu filhote a se mostrar", ele nos faz parte de suas observações de pai de família, que não tinha os recursos, na época, para decifrar a cena do filme relendo-a várias vezes. Senão, ele teria facilmente percebido dois tempos lógicos sucessivos: as cócegas roçando o perigo de uma fogueira pulsional - no caso, aqui, fantasias maternas de devoração já previstas por Freud há um século - e a reorganização em uma forma de admiração narcísica fálica estável em que a mãe vai a partir de então impulsionar seu filho a se exibir. Isto pode chegar até a parada militar nos Champs Elysées, em seu uniforme de politécnico; é da mesma ordem.

Clarisse, que acaba de nascer por fórceps, há alguns minutos, está ainda na sala de parto com sua mãe, enquanto seu pai as contempla e filma, 
emocionado, com sua câmera digital, a primeira troca de olhares entre elas. Com efeito, a mãe a chama ativamente, ela demonstra uma boa pulsão invocante no sentido lacaniano do termo.

Enquanto o bebê, que carrega ainda as marcas do fórceps na fronte, tenta pegar o mamilo, sua mãe o chama: "Opa! Olha só meu bebê! Ah! Aqui! Aqui?'.

Sua voz é suave e modulada, com longas incursões. "Opa! Ob! Opa" parecem acompanhar as tentativas do bebê de se apoderar do mamilo, enquanto que "Olha só meu bebê" e "aqui" são apelos. O bebê não lhes fica insensível, ele volta claramente a cabeça para o alto e busca a fonte da voz de sua mãe. E aí uma báscula completa se opera na mãe. Não somente ela fala no lugar de seu bebê, no que é tradicionalmente descrito há mais de vinte anos, pelos psicolinguistas, como os "turnos de fala", mas ela muda de língua. Ela supõe seu bebê capaz de falar português, primeira língua na qual com efeito Clarisse falará fluentemente aos 2 anos. Essa mãe é ela mesma francobrasileira, ela falou primeiramente em francês com a filha, mas, no momento em que seu bebê a olha, é na língua em que ela foi falada, a mãe quando bebê, que ela supõe que sua filha se expressará. Durante todo o tempo em que a mãe fala, o bebê a olha. Sabemos que uma mãe não pode sustentar um turno de fala sem o olhar franco de seu bebê, e mais tarde sem sua participação vocal tampouco.

[Ela diz, no lugar do bebê]: "De quem é esta voz? Eu conheco esta voz... Eu conheço, é a voz da mamãe".

As incursões são ainda mais marcadas devido à presença insistente do olhar do bebê. Estamos aí diante de um exemplo típico de prosódia do "manhês".

Alguns dias mais tarde, temos uma série de fotos adoráveis que mostram Clarisse em plena forma, usufruindo plenamente do primeiro tempo do circuito pulsional oral: ir até o objeto, na ocasião o mamilo, e se apossar dele. Vemo-la cheirar, beijar, olhar e abrir uma boca devoradora diante do mamilo, sorrir para ele, lambê-lo. Tudo está presente para o primeiro tempo. Mas não há sujeito da pulsão enquanto os três tempos não se instauram. O modo particular com que ela insistiu na questão do terceiro tempo foi o que me pareceu ter valor de ensinamento.

Isso se tornou patente principalmente em torno de seus cinco meses. Antes de pegar no sono, ela tinha de se assegurar de que era um bom objeto para o gozo oral de sua mãe; que seus dedinhos, oferecidos para a boca da mãe experimentar, eram deliciosos para devorar. Trata-se do terceiro tempo do circuito pulsional: o "se fazer comer". Eu tinha conseguido pedir para seu pai tirar algumas fotos desse manejo cotidiano que se repetia no momento da sesta, em que sua mamãe tinha de niná-la alguns minutos para apaziguá-la. As fotos mostram nitidamente como Clarisse, antes de adormecer, abre novamente os olhos para ver que efeito seu presente pulsional tem sobre sua mãe. Essa, desejando acalmar sua filha, cuidava para não exprimir seu gozo de modo algum, todo aquecimento de gozo indo no sentido oposto de seu dever de mãe apaziguadora. Mas o bebê tem ainda necessidade de se assegurar de que ele realmente fisgou o gozo do Outro. Proposição de um enunciado: "meu gozo de bebê é o gozo d'Ela". O que dará mais tarde: o desejo é o desejo do Outro. Por que não falar já de desejo? Porque ele supõe uma operação completa descrita por Lacan (1958-1959) no seminário $O$ Desejo e sua interpretação, na sessão de 11 de fevereiro de 1959.

Ele parte de uma cena descrita por Santo Agostinho (1992), no século IV de nossa era, em Confissões, e comentada muitas vezes por Lacan: uma criança olha seu irmãozinho no seio da mãe. A criança está pálida diante desse espetáculo. "Amaro aspectu”, escreve Santo Agostinho (1992, p. 236), que fala certamente de si mesmo e de sua "inveja do espetáculo amargo de seu irmão de leite". Lacan diz também desse olhar "que ele faz o efeito de um veneno". Erik Porge (1990) escreveu um excelente artigo sobre as variantes de tradução e de interpretação que Lacan pôde dar dessa cena.

Trata-se para Lacan de uma experiência crucial, a do momento lógico fundador do desejo. Essa experiência, cujo alcance é totalmente geral, só pode aparecer através de uma formalização que Lacan desenvolve nessa aula de fevereiro de 1959.

Trata-se de um quadrípodo que consiste na articulação de uma dupla metáfora.

$$
\frac{i(a)}{\$} \diamond \frac{a}{I}
$$

Vejamos então como funciona a dupla substituição.

$$
\text { A primeira é representada por } \frac{i(a)}{\$} \text {. }
$$


O sujeito \$ cai abaixo, enquanto seu irmão de leite, i(a), usurpa seu lugar.

A segunda substituição é representada por $\frac{\mathrm{a}}{\mathrm{I}}$.

O objeto $a-$ no caso descrito por Santo Agostinho, o seio - vem tomar o lugar da mãe ideal, toda Uma, primeira forma do Um, representado aqui por $I$.

Essas duas operações ocorrem de modo concomitante, o que Lacan representa pela punção $\diamond$.

Resta examinar duas outras relações notáveis que resultam da operação de um quiasma: primeiramente, $(\$ \diamond$ a), onde se acha representada a relação (proporção) do sujeito $(\$)$ com o objeto $a$, no caso o seio. O menininho Agostinho descobre seu desejo pelo seio no momento mesmo em que é dele privado pelo usurpador que dele goza em seu lugar. Antes, ele não sabia que o desejava. Mas poderia ser o olhar ou qualquer outro objeto pulsional, a voz que se dirige ao irmãozinho, por exemplo. Em todo caso, é apenas enquanto sujeito privado, marcado pela falta (\$), que ele pode advir como sujeito do desejo, de um objeto $a$, que só se constitui nesse momento. Esse objeto é meu semelhante, que dele goza e assim se constitui minha fantasia de filhote de homem.

Estamos agora em condições de ler a fórmula como se segue: o sujeito $(\$)$ toma consciência do objeto $a$ (aqui o seio) ao mesmo tempo em que toma consciência de que é dele privado por essa outra criança $i(a)$, seu irmão de leite que usurpa seu lugar.

Em seguida: $[i(a) \diamond I]$, que representa uma completude entre o bebê ao seio $i(a)$ e a mãe ideal, $I$.

Essa fórmula parece, pois, representar de modo conveniente o momento em que se instalam, de modo concomitante, o objeto a, o sujeito enquanto desejante, $\$$, e sua relação (proporção) fantasística com esste objeto $(\$ \diamond$ a). Estamos aí em presença da fórmula lacaniana da fantasia.

Se olharmos o grafo do desejo (Figura 1), estamos em condições de enunciar que os dois andares intermediários, que remetem à constituição do espaço imaginário, demandam um tempo para se instaurar. Tempo que não é apenas lógico, mas também cronológico. Eles não estão lá de saída para o filhote de homem. Nosso Agostinho estava neste ponto, diante de seu irmão de leite. Nem Fabien nem Clarisse estavam aí ainda. Grafo completo:

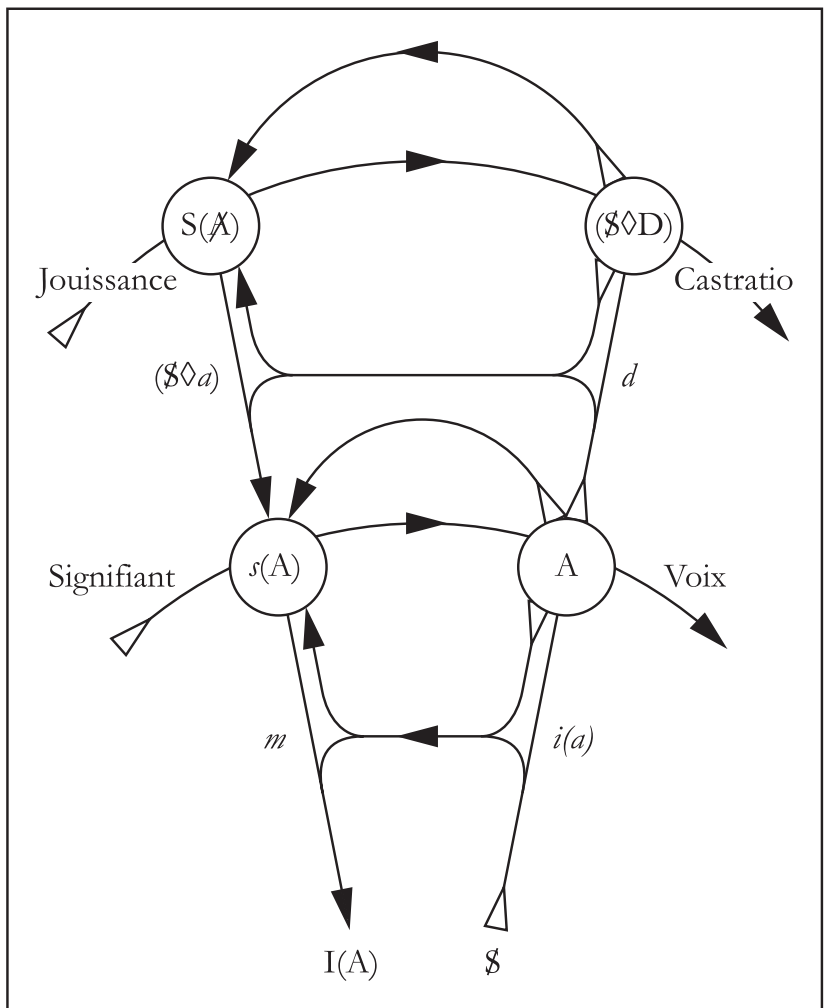

Figura 1 - Grafo do desejo

Nota: Jouissance $=$ gozo

Signifiant $=$ significante

Voix $=$ voz

No tempo primeiro da constituição do aparelho psíquico, apenas a mãe pode ser considerada já constituída como sujeito do desejo. Ora, proponho aqui ler o grafo na perspectiva do bebê. Não posso ainda falar em termos de desejo, mas talvez em termos de um saber S1 que impulsionaria "eu" - o bebê - a me interessar pelo gozo dela $S(\not A)$. E por esse gozo, vimos que os pequenos Fabiens e as pequenas Clarisses são muito interessados, e isso de saída. Isso se junta ao que Trevarthen (2002, p. 86) ${ }^{2}$ enunciou sob a forma de: "The baby is born with a motive for the motive of the other".

\footnotetext{
2 Quando lhe pedem uma tradução para a palavra "motive" em inglês, vêm-lhe desejo, mas ele não tem o rigor de um Lacan quanto do conceito de desejo. Penso que poderíamos dizer "o que convém a um bebê, é o que convém ao Outro". O que remete à questão do gozo.
} 
Há no seminário $O$ Avesso da Psicanálise, nessa mesma aula de 11 de fevereiro de 1970, ainda uma observação à margem, sobre o gozo, a mãe e o bebê, que tem um grande valor para esta clínica precoce. O primeiro a me fazer observar isto foi René Lew.

Eis o enunciado, mas pressupõe que façamos algumas escolhas no modo de colocar as vírgulas num texto oral'. "Os meios do gozo são abertos pelo princípio seguinte, que ele (no caso que nos interessa, o bebê) tenha renunciado ao gozo fechado - e alheio - à mãe" (Lacan, [1969-1970] 1992, p. 74). Poderíamos pensar que é o que Fabien faz, ao largar os pequenos punhos que chupa por preferir as cócegas de sua mãe, chegando até a se oferecer a ela.

O que pude observar em cerca de 40 filmes de bebês que se tornaram mais tarde autistas, e naqueles que pude atender ainda lactentes, é que o bebê futuro autista - por razões que conviria não se precipitar em compreender (a douta ignorância pregada por Nicolas de Cusa é aqui abertura a um saber possível) - não renuncia a um gozo fechado e estranho à mãe. De repente, a possibilidade de um gozo do Outro - a mãe fazendo essa função torna-se impossível. Ao mesmo tempo, o lugar do Outro também.

\section{Um gozo fechado e estranho à mãe: Jérôme}

Para tentar captar de que se trataria esse gozo fechado, tomemos um exemplo clínico concreto, a partir da análise de um filme familiar ${ }^{4}$.

A decifração atenta do filme familiar de Jérôme, bebezinho italiano diagnosticado como criança com autismo aos três anos, é cheio de ensinamentos. Foi somente escutando inúmeras vezes a voz terna e melodiosa da mãe de Jérôme, quando ele não tinha ainda oito dias, que acabamos por decifrar, no movimento repetido de sua mãe diante do rosto dele, que ela se perguntava se ele estaria enxergando-a, de tal modo o olhar do rosto do bebê, que parecia voltado para ela, era vago.

Do mesmo modo, ouvimos a questão patética de sua avó, a quem ele parecia olhar no filme, que lhe pergunta, rindo: "Mas o que você está olhando? Mas o que você está olhando? Faça-me ver!", de tal forma os olhos de seu neto não a olhavam. Ali, nesse último mês, ela faz ainda a hipótese de um sujeito nele e está mesmo pronta para compartilhar sua experiência. Por quanto tempo? Em torno dos 3 meses, seu pai poderá ainda lhe perguntar o que ele quer dizer, desde o primeiro instante em que ele o olha e emite um som; comportamento habitual dos bebês comuns. Ao fazermos uma microanálise de uma cena entre o bebê e sua mãe quando ele tem 1 mês e 20 dias, ouvimos a modificação na voz materna que se cansa, na medida em que todas as suas ternas e doces tentativas fracassam. Mesmo as pequenas carícias em torno da boca não conseguem fazer a atenção do filho se voltar para ela. O pai, que os filma, pede-lhe para tentar ainda. Ela tenta novamente, apoiada pelo pai. Em vão. Uma parada na imagem, no fim dessa cena, permite perceber uma leve ruga de amargura se desenhar no canto da boca materna, certamente à sua revelia. Os pais, diante dessa ausência de resposta do bebê, até mesmo de suas recusas ativas - quando ele se volta ostensivamente para o lado oposto àquele em que se encontra sua mãe - apoiam-se mutuamente e parecem conservar a confiança.

O caso de Jérôme nos permite ter uma pequena ideia de uma das razões possíveis que pode levar um bebê, em risco de autismo, a não olhar um dos pais. Deixo aqui toda causalidade, para interrogar apenas laços entre eventos simultâneos.

Segundo os dizeres dos pais no filme familiar, Jérôme os teria olhado, pela primeira vez, na idade de quase três meses na situação seguinte. $\mathrm{O}$ pai estava deitado no sofá, com seu filhinho contra

\footnotetext{
3 Qual não foi minha admiração no seminário de verão de 2007, sobre o Seminário Avesso, justamente, ao ouvir Claude Landman propor a mesma leitura deste parágrafo! O texto na versão estabelecida é: "que ele tenha renunciado ao gozo fechado e alheio, à mãe" (Lacan, 1970, p. 74).

4 Esses filmes foram generosamente colocados à minha disposição pela equipe de Pisa e gostaria aqui de agradecer ao Prof. Filippo Muratori e à Dra. Sandra Maestro. Nosso encontro se fez na base de nossa paixão comum pela detecção de sinais precoces de autismo no primeiro ano de vida. Eles conhecem os trabalhos da escola de Tours e em particular os de Catherine Barthélémy; eu os escutava. Eu lhes mostrava o que a identificação, a partir da metapsicologia do circuito pulsional, me permitia identificar no contexto dos bebês que eles me mostravam.
} 
suas pernas dobradas. A mãe filmava e os pais falavam entre si, como se fala com um bebê, para se dar força. De repente, suas vozes estavam bastante melodiosas. Num momento determinado, sempre não olhando para ninguém, Jérôme dá um sorriso para os anjos. Isso agrada aos pais e melhora a prosódia de suas vozes, o que tem como consequência desencadear um olhar do bebê para o pai. Então, com a voz embargada de emoção, o pai repete várias vezes, totalmente espantado: "Ele está me olhando! Ele está me olhando! Ele está me olhando?'. A alegria do pai se ouve claramente. De repente, o bebê emite um som em direção ao pai que, imediatamente, muda de registro e lhe pergunta "O que você quer dizer?” Risos de felicidade sacodem a voz da mãe e do pai. Mas esse último aceita muito bem quando o bebê quer cortar a relação; ele concorda com seu filho.

Os risos dos pais de Jérôme, que olha para seu pai e gorjeia, apresentam as subidas e descidas típicas da surpresa e da alegria, o que constitui a curva do que se nomeia prosódia do manhês. Como posso estar certa disso?

A gravação dessas vozes - como a de vários outros pais de bebês da coorte de Pisa - foi objeto de uma pesquisa multidisciplinar. A psicolinguista Erika Parlato ${ }^{5}$ colabora conosco. Ela estudou as gravações da prosódia das vozes dos pais de Jérôme comparando-as com as de pais italianos que nossos colegas de Pisa lhe forneceram. Ela afirma que cada vez que Jérôme olha, é em presença de uma prosódia específica, descrita pelos psicolinguistas como o motherese ou, mais recentemente, o parentese, pois os pais também o praticam muito bem. Em português isso se traduz por manhês e paiês, como dizemos o francês ou o inglês.

Dez minutos mais tarde - como está indicado na película de vídeo - a mãe toma seu bebê nos braços e se põe a falar com ele. Sua voz está ainda impregnada pela surpresa e pela alegria do acontecimento que acabou de se produzir, o que se traduz nas curvas prosódicas de sua voz.

Com efeito, desde um de seus primeiros artigos sobre a prosódia do "manhês", A. Fernald (1982) fizera observar que esta forma particular de prosódia em uma mãe não se encontrava praticamente nunca na linguagem de um adulto se dirigindo a um outro adulto, salvo em condições extremamente raras, em que uma grande surpresa ocorria junto com um grande prazer. $\mathrm{O}$ autor não tirou disso nenhuma consequência, mas eu ficara extremamente interessada por esses dois termos: surpresa e prazer. Eles vinham recobrir as noções de espanto e de iluminação que tanto tinham interessado Freud (1940) no lugar da terceira pessoa do dito espirituoso. Eu as retomara a propósito de meus tratamentos psicanalíticos de uma criança autista (Laznik, 1997).

Como a mãe de Jérôme se dirige ao filho com uma voz carregada dessa prosódia, ele não pode deixar de olhá-la; isso me levou a pensar em uma dimensão de voz de sereia na voz da mãe. Mas, desde que esse bebê vê o rosto de sua mãe, ele se põe a chorar. Por quê?

Quais hipóteses podemos fazer aqui? Tratar-se-ia de uma dificuldade com a intermodalidade, de passar do ouvido ao visto? Mas com seu pai, dez minutos antes, o bebê não apresentou essa dificuldade. Teria ele visto algo de tão desagradável? Talvez os traços do rosto materno? As preocupações diante de um bebê que não responde se apagam talvez mais lentamente num rosto do que em uma voz. Não esqueçamos a leve ruga de amargura que começava a despontar no canto de sua boca.

Três dias mais tarde, a mãe conseguirá entrar em um longo intercâmbio com seu bebê. Os dois estão deitados na cama do casal e o bebê deve fazer um esforço para se voltar para o rosto materno, parcialmente oculto pelo colchonete no qual ele repousa. É possível que a posição bem relaxada da mãe tenha contribuído para a qualidade de sua prosódia, mas pode-se pensar também que a posição do rosto materno impedia uma leitura muito fina de ínfimos traços de preocupação nesse rosto. Desde que o bebê lhe responde, olhando-a, a surpresa e a alegria da mãe irrompem, melhorando ainda sua prosódia. Ela lhe diz um monte de palavras gentis, declarando-lhe seu amor de todas as formas possíveis e ri de alegria com as respostas do filho. Mas, embora possa retomar em eco algumas de suas vocalizações, ela não se permite falar no lugar dele na primeira pessoa do singular. Ela não lhe atribui frases que se endereçariam a ela, a mãe. Por causa disso, seria talvez necessário falar de pseudo protoconversação. Essa dimensão louca que

\footnotetext{
5 Ela trabalha na Faculdade de Medicina de Belo Horizonte, em Minas Gerais, e faz sua tese de Doutorado em Psicolinguística com o Professor Dupoux do Laboratoire de Sciences Cognitives da École Normale Supérieure de Paris.
} 
consiste em falar no lugar do outro - no sentido de Winnicott (1978), da loucura necessária das mães talvez só seja possível em condições de segurança da capacidade materna. Um bebê que não responde deve colocar sua mãe à prova duramente.

Mas, sobretudo, Jérôme não apresenta, em todo o filme de que dispomos, nenhum sinal do terceiro tempo do circuito pulsional. Não somente não busca se fazer ouvir como, mesmo estimulado por sua mãe, não procura se fazer o objeto da pulsão dela.

Uma cena instrutiva é aquela em que, no trocador, a mãe brinca de estimular seu filho. Ela lhe mostra como seu pezinho é apetitoso, chegando até a lho oferecer para provar, o que o bebê aceita, não sem certo prazer. Mas não lhe viria realmente à ideia oferecer esse pezinho à boca de sua mãe, contudo tão próxima. Não é um bebê que goste de se fazer mordiscar pelo Outro. Ele não parece se interessar pelo que poderia dar prazer a este outro. Citamos mais acima Trevarthen: se os bebês nascem com $a$ motive for the motive of the other, não é o caso dos bebês que se tornam crianças com autismo, que assistimos nos filmes familiares.

No plano metapsicológico, não falo mais do terceiro tempo do circuito pulsional como sendo aquele da passivação pulsional. Compreendi que para Lacan há uma pequena distinção, muito útil para a clínica dos bebês que se tornam autistas. Ele fala de uma "voz mediana", como se expressa Émile Benveniste (2008), voz mediana entre a atividade e a passividade, não é a passivação pulsional, é o "se fazer", é o que permite distinguir um registro puramente narcísico de um registro pulsional, o que infelizmente existe em certos casos. Jérôme é um exemplo disto. Num trocador, um bebê pode se deixar beijar por sua mamãe e mesmo mostrar um rosto completamente satisfeito com o que se passa, sua capacidade de passivação parece não ser ruim. Entretanto, o fato de que em nenhum momento ele tenha reversão pulsional, que em nenhum momento ele tome as rédeas da situação, para se fazer ele mesmo objeto da mãe e dar seus dedos da mão para a dama chupar - e já que estamos aí, por que não os pés também - para ver se isso lhe agrada, se é uma alegria para ela, é preocupante. Aí não estamos mais no registro da passivação pulsional, mas no da reversão pulsional, e é esse registro que falta nos filmes dos bebês que se tornam autistas. Eu poderia mesmo dizer que a passivação pulsional é justamente o que alguns demonstram.

Do ponto de vista da mãe, ela não precisa recuar de uma posição de gozo libidinal erótico para uma posição mais fálica narcísica. Ela só tem essa última.

Os pais de Garance, que atendo, traduzemme sua capacidade de passivação dizendo que, quando bebê, ele gostava de pequenas massagens e carícias após o banho, o que é bem evidente nos filmes que eles me emprestaram. Mas não há nenhum vestígio de reversão pulsional em seus filmes. Nunca.

De que se trata esse gozo fechado do bebê?

Temos esboços disso na oposição que Freud (1905) propõe desde os Três Ensaios para uma Teoria da Sexualidade entre narcisismo do Ich (sou obrigada a deixar aqui o alemão porque moi [eu, mim mesmo], em francês, remete a uma instância imaginária que supõe já o estádio do espelho instaurado) e narcisismo do objeto. Entretanto, há muitos anos, eu não conseguira responderà questão colocada por um grupo de trabalho de Denise Traunschweig (1971) sobre a distinção entre narcisismo e pulsão em Lacan. A questão foi formulada a partir do esquema ótico e do objeto $a$. $\mathrm{Na}$ época, eu não tinha clínica diferencial para colocá-la a trabalho, apesar de transitar por esses elementos teóricos, razão pela qual tinha sido convidada para esse grupo de leitura sobre Lacan. Há cinco anos, um grupo lacaniano no $\mathrm{Brasil}^{6}$, discutindo um artigo que eu escrevera sobre a pulsão em Lacan (Laznik, 1994), lembrava-me que eu ressaltara ali que pulsão de vida e pulsão de morte são para Lacan uma mesma biface (como a banda de Moebius) e que ele coloca o dualismo do lado de uma oposição entre o campo das pulsões (que são todas sexuais e parciais) e o campo narcísico do amor. Eles me pediam para demonstrar clinicamente essa questão. Eu lhes disse que não era capaz de fazer isso. Pois bem, foi um pequeno Matteo, que tinha deixado minha amiga Sandra Maestro, da equipe de $\mathrm{Pisa}^{7}$ extremamente perplexa, que me deu

6 Trata-se da Escola Lacaniana de Vitória, no Espírito Santo, que tinha trabalhado todo o ano sobre a questão da pulsão e, entre outros, sobre meu artigo "Por uma teoria Lacaniana das pulsões" (Laznik, 1994).

7 Mas também psicanalista da IPA, aluna de Frances Tustin. Não esqueçamos que, em inglês, pulsão foi oficialmente traduzida por instinto na Standard Edition, o que não simplifica em nada para nossos colegas anglo-saxões. 
a resposta. Este bebê não correspondia ao que ela via, habitualmente, nos bebês que se tornavam em seguida autistas. Ele era um magnífico caso de uma construção fálica narcísica sem que, paralelamente, se construísse a questão pulsional. Nestes casos, o quadro sintomático só desaba no segundo ano de vida. Trata-se de uma clínica dura para analisar humanamente, no plano subjetivo, transferencial. Diante desses filmes, somos confrontados com um bebê que parece responder à vOz de seus pais e ser muito sensível aos elogios narcísicos fálicos de seu pai e que será, contudo, incapaz de ter um movimento espontâneo qualquer na direção deles, desde que, tendo adquirido a marcha, eles esperarão, com razão, que o bebê se movimente na direção deles. Os ensinamentos metapsicológicos que se podem colher são interessantes. As pesquisas com os recémnascidos de algumas horas mostram um toquinho de gente de proto-sujeito com uma apetência absolutamente extraordinária para direcionar-se ao que convém ao outro. Eles vão procurar o outro, por eles mesmos. Eles empurram para que haja Outro. Isso parece dar razão aos mais loucos devaneios da bruxa Dolto, mesmo que suas conceituações fiquem longe do rigor que os lacanianos têm o direito de esperar. Enquanto que os filmes dos recém-nascidos, futuros autistas, mostram neles uma determinação selvagem para recusar o contato. Pode-se trabalhar isso, mas é preciso arte e não qualquer voz, a da sereia e não outra.

Antes de descrever uma cena com o pequeno Matteo, vejamos sob quais aspectos da teoria de Lacan pude me apoiar. Lacan retomará esta questão de um gozo fechado à mãe enquanto Outro no Seminário XX, a propósito da impossibilidade da relação (proporção) sexual, ligando-a ao gozo do órgão fálico. René Lew (2004), partindo desse desenvolvimento lacaniano, proporá opor o gozo fálico ao gozo do Outro. Desde então, para ele, o autismo seria um sucesso perfeito dessa não relação, pois o autista estaria preso a um gozo fálico de seu próprio corpo. Como toda hipótese, ela é simplificadora, mas tem o mérito de reintroduzir a questão do gozo do Outro como um elemento constitutivo do aparelho psíquico do filhote de homem.

Ela permite cruzar novamente esse gozo do Outro $\mathrm{S}(\not X)$, inscrito no grafo do desejo, com o registro mesmo da pulsão e inscrito também nas fórmulas da sexuação no Seminário XX.
A passagem entre os dois se faz no Seminário $X X$, quando, a propósito da pulsão, Lacan fala de fisgamento do gozo no campo do Outro, no terceiro tempo do circuito pulsional.

O que Lacan não sabia na época do Seminário XI (1964) é que a semiótica de Pierce (que ele pedirá a Récanati para lhe expor) o levará a uma teoria da função que nos permite avançar que é no momento mesmo em que esse gozo é fisgado no campo do Outro (o que supõe, para que haja gozo, que um outro em carne e osso queira realmente se prestar a ocupar esse lugar), que é apenas aí que o campo do Outro pode se constituire, retroativamente, a função sujeito propriamente dita.

Este último Lacan, marcado por Frege e, sobretudo, pela semiótica de Pierce, parece-me ser o único caminho metapsicológico possível para dar conta do impasse em que os analistas se colocaram a propósito do autismo - na busca desvairada por uma causalidade no aparelho psíquico da mãe capaz de dar conta do autismo do filho.

Além disso, no campo psicanalítico, isso permite pensar uma clínica de um gozo fechado à mãe, com seu corolário, a não instalação do campo do Outro.

Lew fala de

compactação do gozo no autismo [...] o sujeito autista está compactado em seu narcisismo, identificado com o Um, sem Outro distinguível. Se há realmente um gozo para o autista, é então um gozo do corpo: o interesse, quando existe, é pela comida, pela troca de roupa, pelo movimento estereotipado... Dir-se-á então que o gozo corporal do autista é, contudo, fálico - o corpo inteiro tendo então valor de falo? Eis aí uma posição sustentável, pelo menos se falarmos do autismo próprio à esquizofrenia. Seria possível defendê-la para o autismo infantil primário? (Lew, 2004, p. 12).

Vejamos como isso se passa na clínica de Matteo que nos ensinou tanto. Como Jérôme, Matteo é, nos primeiros meses de vida, um bebê bastante inexpressivo, que seus pais solicitam muito. Mas, contrariamente a Jérôme, ele não chega a prejudicar a prosódia de sua mãe, pelo menos quando o pai está lá. A voz de sereia da mãe tem ganho de causa. Ela consegue ultrapassar o muro da indiferença de seu filho e vencer a atração dele pelo móbile das 
abelhas. Exatamente o mesmo que atrai tanto Jérôme aos 2 meses e meio! Matteo, por sua vez, prefere a voz de sua mãe. É verdade que ele já tem 6 meses e que sua mãe tem uma voz que canta os louvores do filho adorado que, desde aquela manhã, já sabe rolar sozinho no berço! O que ele vai mostrar ao papai, "não é, meu tesouro?" O tesouro está chuffed, como diria Trevarthen, de ser a este ponto a fonte do orgulho narcísico dessa mãe. E ele a acresce. Ele repete e repete sua exibição narcísica.

Posso compreender que ao comparar essas duas cenas, aparentemente tão diferentes, que ocorrem no mesmo contexto, mesmo que com três meses de idade de defasagem, meus amigos de Pisa tenham chegado a falar de duas categorias distintas de autismo. Essa da qual Matteo faria parte apresentaria distúrbios principalmente no segundo ano de vida.

Uma outra cena, entre Matteo e seu pai, parece aí também lhes dar razão. Matteo tem 10 meses e meio e já é capaz de ficar de pé, sozinho em seu berço, estimulado pelas palavras do pai, que o encoraja como um treinador faria com um campeão esportivo. O bebê vai se levantar, se manter sobre suas perninhas, fazer esforços intensos para corresponder à ereção narcísica fálica que o pai propõe de sua imagem. Não sem prazer. Até que a dor física em suas perninhas fica muito forte e ele cai. Ele se regozija de ser o falo erigido, no que não é infelizmente perverso - se não vai em direção ao pai, é porque se trata de um gozo compacto, fechado para seu pai também. Desse último, ele não tem cura. $\mathrm{O}$ que se verá muito rápido no mês subsequente. Ele não se direciona para ele. Nem para ninguém, aliás. $\mathrm{E}$ as vozes se calam. $\mathrm{E}$ a ereção narcísica desaba. $\mathrm{O}$ que meus amigos chamam de "entrada no autismo no segundo ano de vida".

O que esses dois bebezinhos têm em comum é que tanto um quanto o outro não desenvolveram uma sexualidade infantil em seu primeiro ano de vida, no sentido freudiano do termo - e a concepção lacaniana de uma dualidade opondo o campo das pulsões propriamente ditas ao campo narcísico do amor é muito útil para compreender esses casos. Qualé a diferença entre Jérôme e Matteo? Esse último engana no primeiro ano de vida, pois desenvolve o campo fálico narcísico graças às imensas qualidades acústicas da voz de seus pais.

Esse gozo, fechado à mãe, esse gozo fálico (JФ) compacto, remete-me ao não desdobramento do terceiro tempo da pulsão, tempo em que o $I c h$ - no caso, o bebê - vai fisgar o gozo no campo do Outro.

O que a clínica do caso de Denys deveria me ensinar na sequência é que não basta que o bebê queira ir atrás para fisgar esse gozo. É preciso que ele seja bem-sucedido, que alguém queira realmente deixar seu gozo ser fisgado, instaurando assim o campo do Outro. Mas isso será assunto de outro artigo.

\section{REFERÊNCIAS}

Benveniste, E. (2008). Problemas de linguística geral 1. São Paulo: Pontes.

Braunschweig, D. (1971). Eros et Antéros, réflexions psychanalytiques sur la sexualité. Paris: Payot.

Fernald, A., \& Simon, T. (1982). Expanded intonation contour in mother's speech to newborns. Developmental Psychology, 20(1), 104-113.

Freud, S. (1940). Le mot d'esprit et ses rapports aec l'inconscient. Paris: Folio Essais.

Freud, S. ([1905] 1972). Três ensaios sobre a teoria da sexualidade. Rio de Janeiro: Imago.

Lacan, J. (1979). Seminário, livro 11: Os quatro conceitos fundamentais da psicanálise. Rio de Janeiro: Jorge Zahar.

Lacan, J. ([1972-1973] 1985). Seminário 20: Mais, ainda. Rio de Janeiro: Jorge Zahar.

Lacan, J. (1992). Seminário, livro 17: $O$ avesso da psicanálise. Rio de Janeiro: Jorge Zahar.

Lacan, J. (2009). Seminário, livro 18: De um discurso que não fosse semblante. Rio de Janeiro: Jorge Zahar.

Laznik, M. C. (1994). Por uma teoria Lacaniana das pulsões: Dicionário Freud-Lacan. Salvador: Ágalma.

Laznik, M. C. (1995). Vers La parole: Trois enfants autistes em psychanalyse. Paris: Denoël.

Lew, R. (2004). Fonction de lajouissance dans 1'autisme. Texto apresentado nas Jornadas Préaut/ALI, Autisme, actualités des différentes recherches, Paris.

Peirce, C. S. (1960). Collected papers. Harvard: Harvard University Press.

Porge, E. (1990). La frérocité. Revue Littoral, 30, 11-30. 
Santo Agostinho. (1982). Confessions, VII. Paris: Seuil.

Trevarthen, C. (2002). Autism, sympathy of motives and music therapy. Enfance, 54(1), 86-99.

Trevarthen, C. (2005). First things first: Infants make good use of the sympathetic rhythm of imitation, without reason or language. Journal of Child Psychotherapy, 31(1), 91-112.

Winnicott, D. W. ([1956] 1978). Da preocupação materna primária. In D. W. Winnicott. Da psiquiatria à psicanálise (pp. 491-498). Rio de Janeiro: Francisco Alves.

Recebido: 23/03/2009

Received: 03/23/2009

Aprovado: 04/05/2009

Approved: 05/04/2009 